\title{
Welding by Hot Forging of Two Carbon Steels for the Manufacture of Spanish and Japanese Weapons
}

\author{
Duarte A, Queirós GW, García Sanchez L*, Gómez de Salazar JM and Criado Portal AJ \\ Department of Materials and Chemicals Engineering, Faculty of Chemistry, Complutense University of Madrid, 28040 Madrid, Spain
}

\begin{abstract}
The technologies of manufacture of medieval and modern weapons in Spain and Japan, keep a very remarkable similarity. Through different paths and sensitivities, the use of steel was achieved with a common idea: hardness, resistance and toughness; all combined in a single set of steel.
\end{abstract}

Keywords: Weapons; Steel; Steel Technology; Mechanical properties; Welding

\section{Introduction}

In this study, the aim is to compare Spanish and Japanese steel, to reproduce the technologies used in the manufacture of arms in both steels. Although the combat models are different, the technological solution found for the two knives in both countries is the same: hot forging of two steels of different carbon content.

The names of these weapons are different, but the typology is the same, if we accept the slight curvature of Japanese weapons; curvature that in Spain is less common.

Spanish weapons, depending on their size, can be classified into: blades, swords, daggers and daggers, with different varieties. And in Japan, the resemblance is as follows: katana (blade), wakizashi (sword, including daggers) and tantó (knife) (Figures 1 and 2). In the medieval

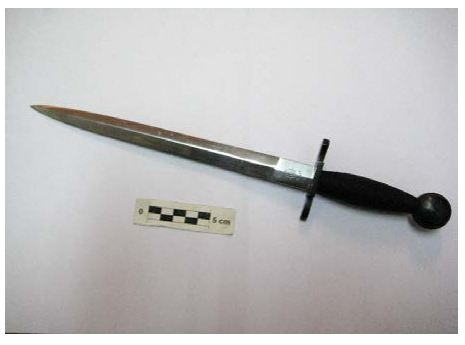

Figure 1: Exact steel reproduction of Toledo (Spanish) that accompanied Emperor Charles $\vee$ to Juste.

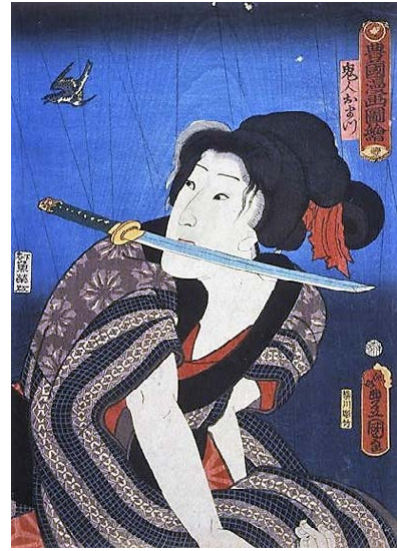

Figure 2: Engraving of Utagawa Kunisada (1786-1864). Actor with a Wakizash in his mouth. world, the sword goes beyond all the concepts of a warlike instrument and becomes something magical and sacred. If we read the Song of Roldan, there are many paragraphs that refer to "Durandarte", the sword of Count Roldan, Carlomagno's leader, in the battle of Roncesvalles; it says so (El Cantar de Roldan, CLXXIII):

"Roland strikes against a black rock, and hits it to the point that I don't know how to tell you. The sword neither crackles nor breaks, but jumps toward heaven. When the Count sees that he cannot break it, he weeps very sweetly from his heart: Ah Durandarte, how beautiful and holy you are! Your golden knob is full of relics. There is a tooth of St. Peter, blood of St. Basil, hairs of my lord St. Dionysius and a piece of Santa Maria's tunic. It is not the law to be taken from you by the infidels: only to Christians must you be trusted. I hope you never come to power of a coward! For you, how many vast lands I will have conquered, which today has Carlos, the one with the flowering beard! For them, the emperor is rich and powerful".

The sword ceases to be the extension of the warrior's arm and becomes the protagonist of the fight; its magic and holiness protect its possessor. This alone is the bearer of a magical object. It can fail the arm, never the sword.

Wear resistance on the blade, effective cutting and strength in the sword assembly is provided by high carbon steel, while the necessary toughness, so that the weapon does not split during the fight, is provided by low carbon mild steel. These steels of such disparate carbon content must be placed according to the style of combat, in order to be more effective (Figure 3). Obviously, the two steels together must be intimately united to counteract and enhance their characteristics, and this is achieved with hot forging welding.

In this research we have tried to reproduce the forging technologies of these weapons; following at all times the scientific data and contributions given in the international literature, based on numerous studies of Spanish and Japanese steel specimens [1-5].

*Corresponding author: Laura Garcia Sanchez, Department of Materials and Chemicals Engineering, Faculty of Chemistry, Complutense University of Madrid, Spain, Tel: (+34) 91.394.42.86; Fax: (+34) 91.394.43.57; E-mail: gslaura@quim.ucm.es

Received April 05, 2018; Accepted April 12, 2018; Published April 22, 2018

Citation: Duarte A, Queirós GW, Sanchez LG, de Salazar JMG, Portal AJC (2018) Welding by Hot Forging of Two Carbon Steels for the Manufacture of Spanish and Japanese Weapons. J Material Sci Eng 7: 446. doi: 10.4172/2169-0022.1000446

Copyright: (C) 2018 Duarte A, et al. This is an open-access article distributed under the terms of the Creative Commons Attribution License, which permits unrestricted use, distribution, and reproduction in any medium, provided the original author and source are credited. 
Citation: Duarte A, Queirós GW, Sanchez LG, de Salazar JMG, Portal AJC (2018) Welding by Hot Forging of Two Carbon Steels for the Manufacture of Spanish and Japanese Weapons. J Material Sci Eng 7: 446. doi: 10.4172/2169-0022.1000446

Page 2 of 6

\section{Experimental Technique}

The techniques used for the study were: selection of steels, creation of the mechanical model, and preparation by hot rolling, traditional hot forging (master J. Pozón), machining, hardening in water, tempering and grooming. And, the scientific techniques used during the scientific-technical study were: Rockwell $\mathrm{C}$ and Vickers hardness, optical metallography and scanning electronics.

The steel selected for both models (Spanish and Japanese) were: UNE F1110 (DIN CK15) and UNE F1150 (DIN CK55). The steel F1150 is the steel chosen for the exterior areas due to its good water quenching and its similarity with the hard steels used by the medieval and modern master swordsmen. For the very soft steel core of the interior, F1110 has been used, due to its absolute similarity with the steel core of the swords under study [6-9].

The models selected for the forging of both sets have been the tile model and the sandwich model, for Spanish steel (Figures 4 and 5).

And the " $\mathrm{U}$ " and "V" tile model for Japanese steel. It can be seen how, in the tile model, the mild steel F1110, reaches the upper edge of the tile, to form the spine of the sword (Figures 6 and 7).

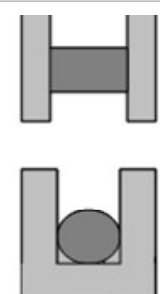

$\square$ Fe- 0.1C

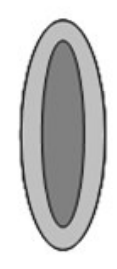

Fe- 0.6C $\square$ Fe-0.1C $\square$ Fe- $0.6 C$

Axial view of Spanish steel

Figure 3: Spanish and Japanese steel forging model.

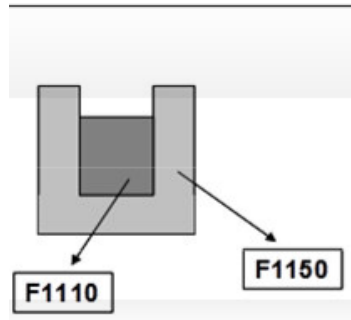

Tile model
Figure 4: Diagram of the steel model for the Spanish steel forging
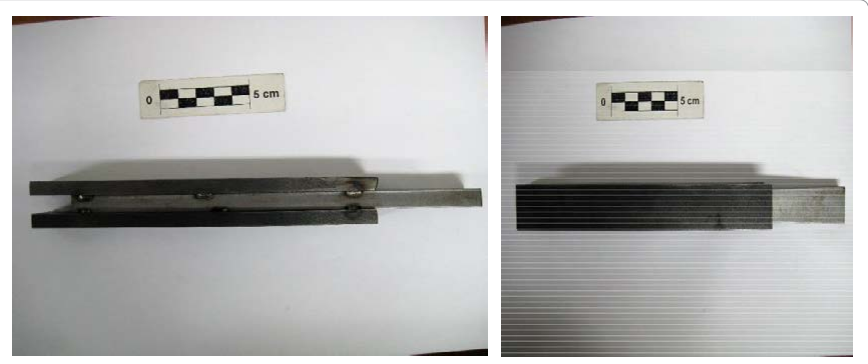

Figure 5: Steel model for the forging of Spanish steel.
Before the classic hot forging in the forge, the preparatory action is carried out by hot rolling of the model (Figures 8 and 9) [10-12].

This preform, with which the steel of the interior is already attached to the roof tile or sandwich, is passed to the classic forging at the hands of the master D. Juan Pozón (Figures 10 and 11).

The sandwich, already welded by forging on the hot-rolling machine, is given its final shape by hammering on the anvil, thus reaching the final shape (Figures 12 and 13). For Spanish steel, the steps are the same, but the edge is forged on the two sides of the blade. Scaling with steel brush, it is passed to the hardening stage in water. Here the hardening has certain variations for both steels, related to the
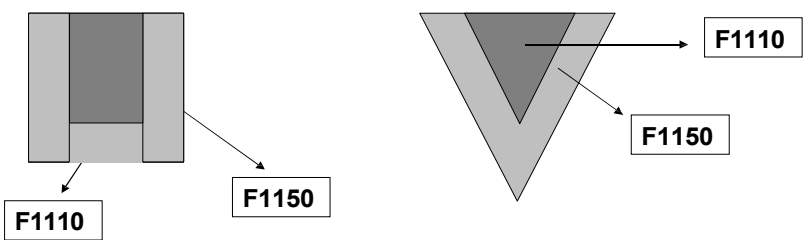

\section{"U" and "V" tile model.}

Figure 6: Diagram of the steel model for Japanese steel forging.

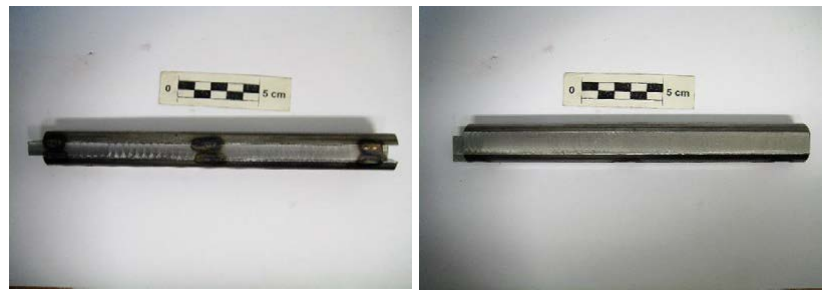

Figure 7: Steel model for Japanese steel forging.

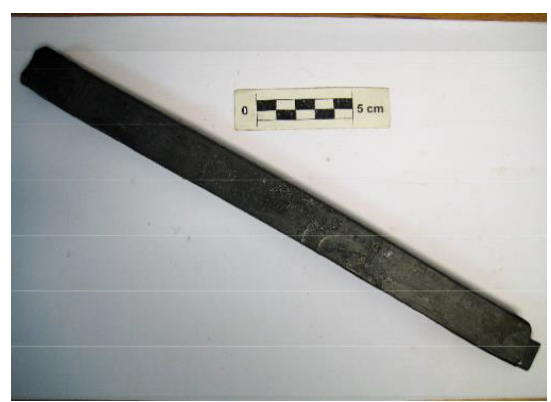

Figure 8: Hot rolling of the katana model; side view.

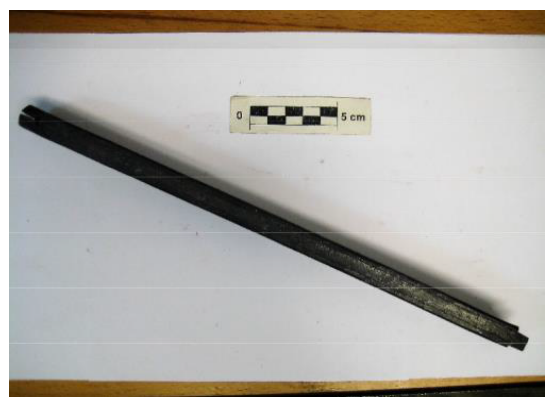

Figure 9: Hot rolling of the katana model; profile view. 


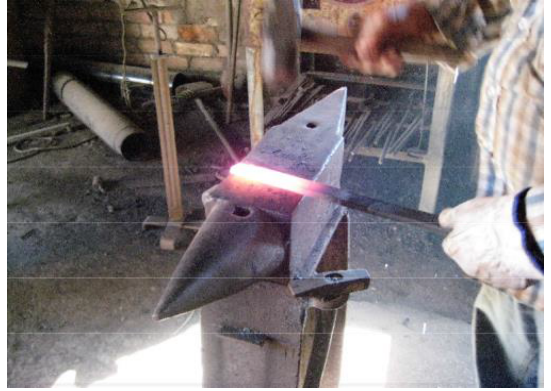

Figure 10: Start of hot forging of the katana model.

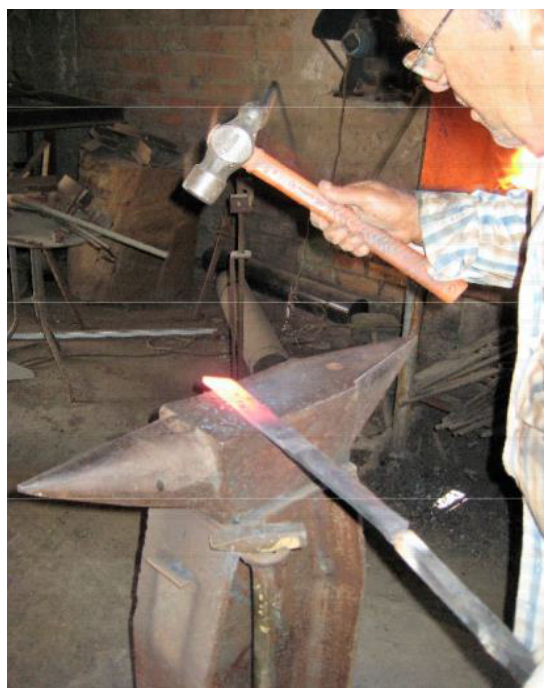

Figure 11: Stretching by hot forging until the desired length is obtained.

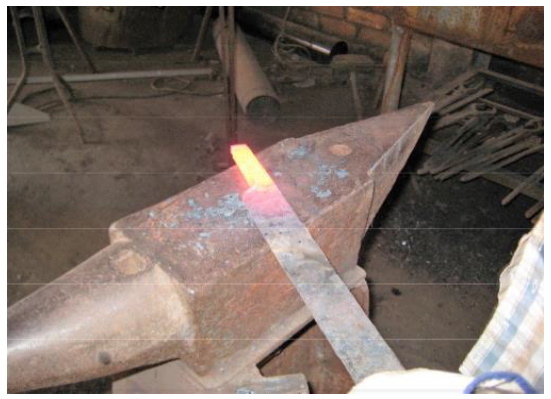

Figure 12: Practically finished form of the wakizashi (a true Japanese sword from 30 to $60 \mathrm{~cm}$ ) in front of the katana that was more than $60 \mathrm{~cm}$ long.

distribution geometry of the two steels, soft and hard, in steel blades: For the case of wakizashi, see Figures 13-15.

Final grooming is a fundamental step in the manufacture of these knives; it gives them the final appearance and shape. In Japan, the grooming master is the most valued [12-15].

\section{Results}

The metallographic study is fundamental for the follow-up of the results of the application of the techniques of manufacture of these weapons.

A macrograph of Spanish steel is shown in Figure 16. It is a soft
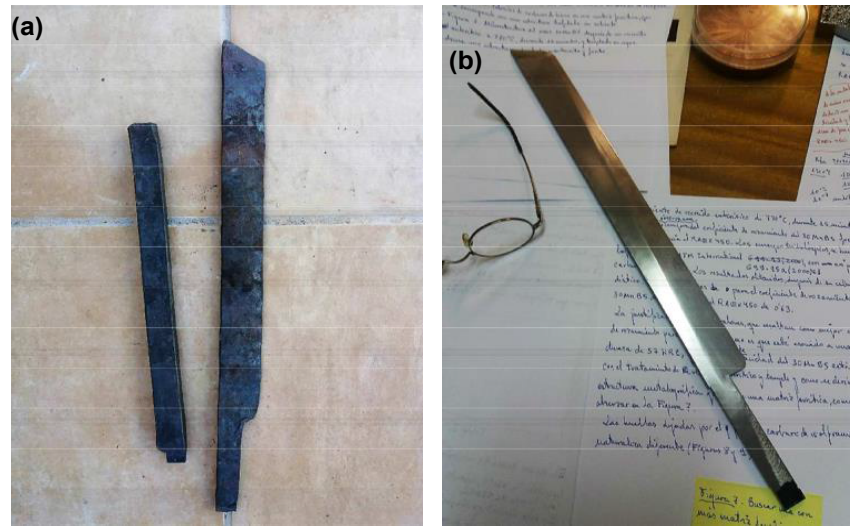

Figure 13: (a) Appearance of the wakizashi hot forged by the master $D$. Juan Pozón. (b) Clean and slightly machined wakizashi aspect ready for hardening.

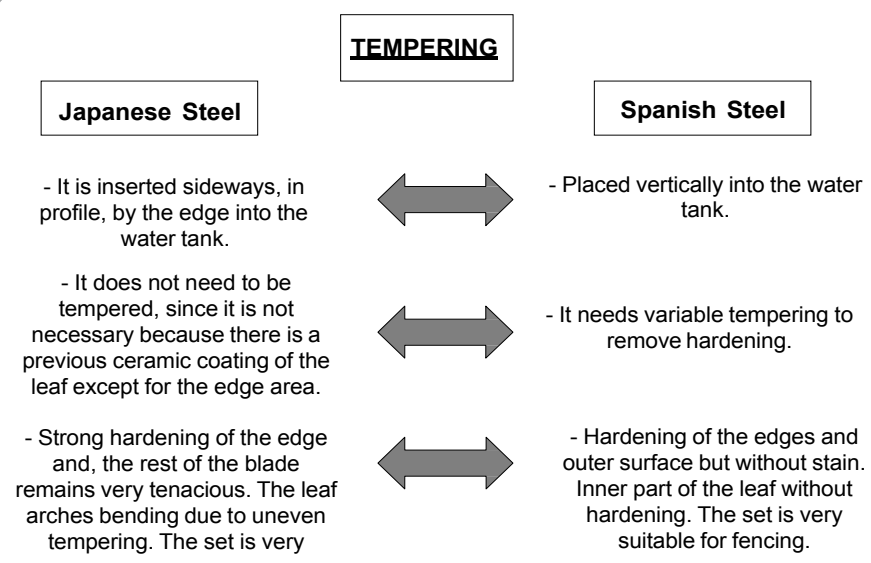

Figure 14: Tempering of Steel.

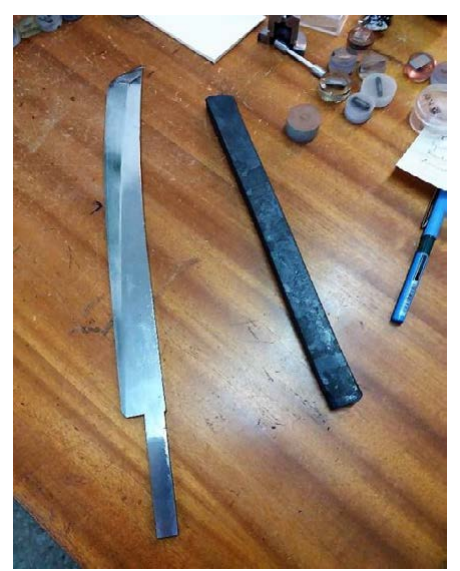

Figure 15: Wakizashi tempered and groomed in the absence of the hilt Observe the curvature of the hardening.

steel sandwich inside and hard steel outside, hardened and tempered.

The macrograph of Japanese steel shows a sandwich of the two steels, but incomplete, open at one end in a U-shaped shape, which coincides with the spine of the sword (Figure 17).

In both Spanish and Japanese steels, the bonding by hot forging is excellent; making the bonding of the two steels a remarkable joint (Figure 18). 
Citation: Duarte A, Queirós GW, Sanchez LG, de Salazar JMG, Portal AJC (2018) Welding by Hot Forging of Two Carbon Steels for the Manufacture of Spanish and Japanese Weapons. J Material Sci Eng 7: 446. doi: 10.4172/2169-0022.1000446

Page 4 of 6

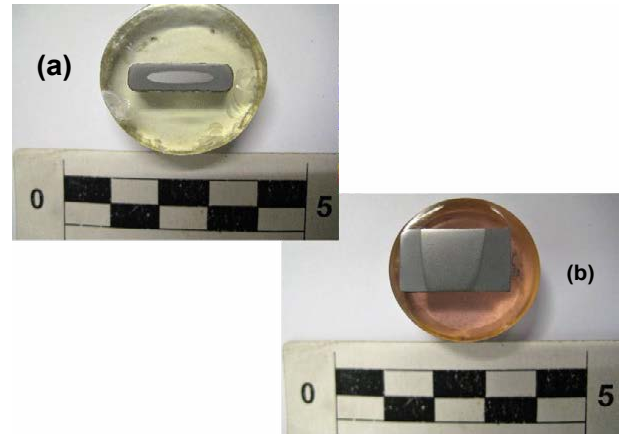

Figure 16: (a) Axial cross-section of the Spanish hardened and tempered steel model. (b) Axial and transverse cross-section of the Spanish steel model.

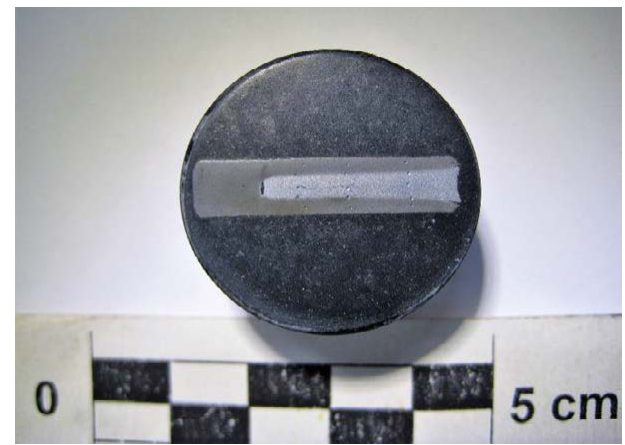

Figure 17: Macrograph of an axial cut of Japanese steel. Hard steel U-shaped wraps the soft steel inside. It's tempered. The union is not perfect because the hot forging stage in the forge is still missing.
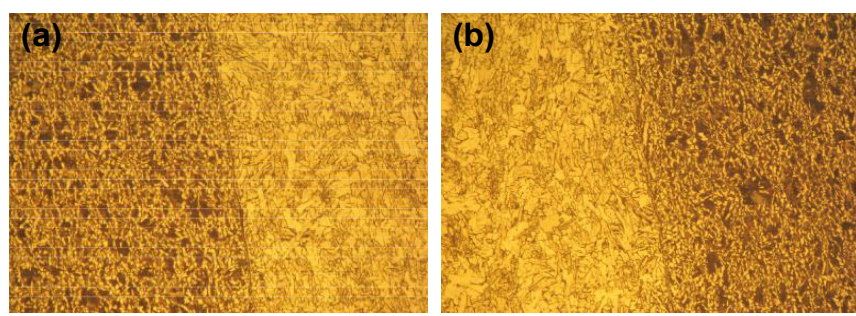

Figure 18: (a) Micrograph corresponding to one of the junction interfaces of the two steels, soft and hard. Note that the connection is very correct. (b) The other junction interface of both steels.

In the Figure 19, soft and hard steel are clearly joined together by means of a fine interface of ferrite crystals. This ferrite always appears in the union of both steels of such different carbon composition. The union is therefore very tenacious and effective [16-19].

In scanning electron microscopy, this ferrite band is more clearly visible (Figures 20 and 21).

The hot forging welded joint preserves the ferrite band, despite the heat treatment of hardening and tempering, as can be seen in Figures 22 and 23 .

Vickers HV30 hardness tests, along the profile of the cross-section of the leaf, show how in the water hardening stage, from $850^{\circ} \mathrm{C}$, it hardens the outer layer in a remarkable way and, as soon as it remains with the same hardness in the Spanish and Japanese steel. For Japanese steel, the weapon is thus left without any later stage; since, due to the

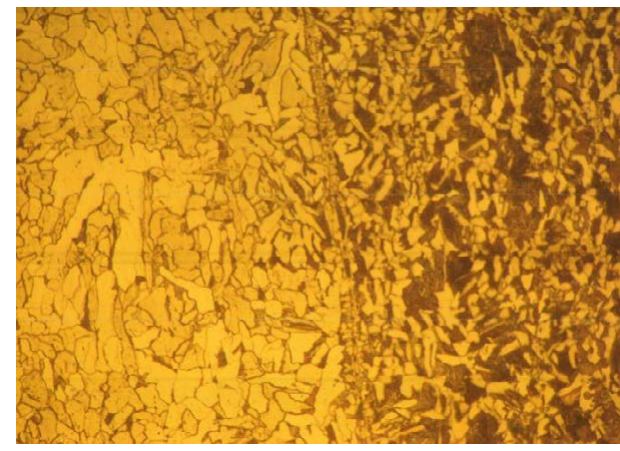

Figure 19: In this micrograph, the bonding interface of the two steels is clearly visible, welded by hot forging using a continuous row of ferrite crystals.

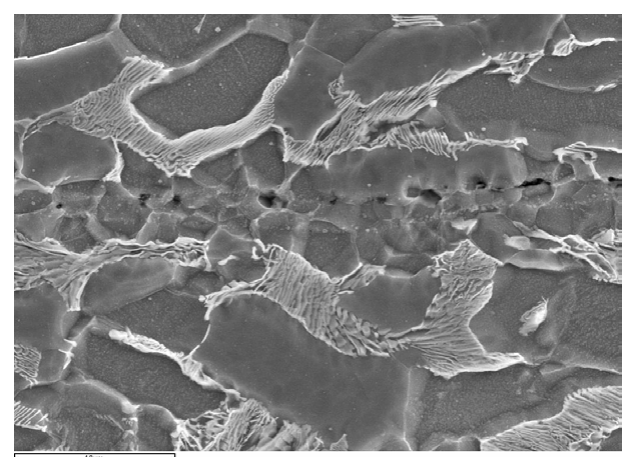

Figure 20: Micrography obtained by M. E. B. where the ferrite band of the welding interface is shown.

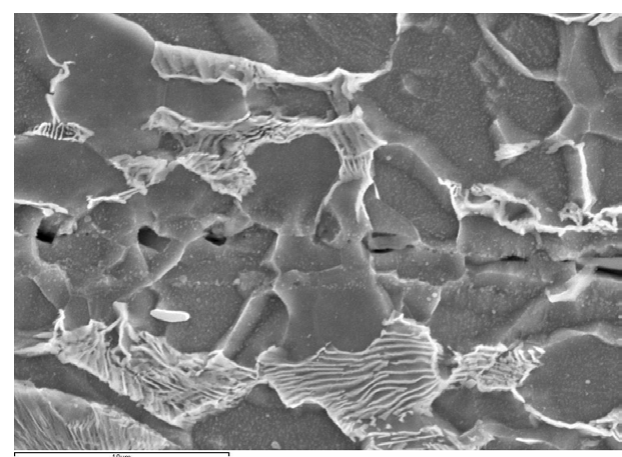

Figure 21: Detail of the previous figure.

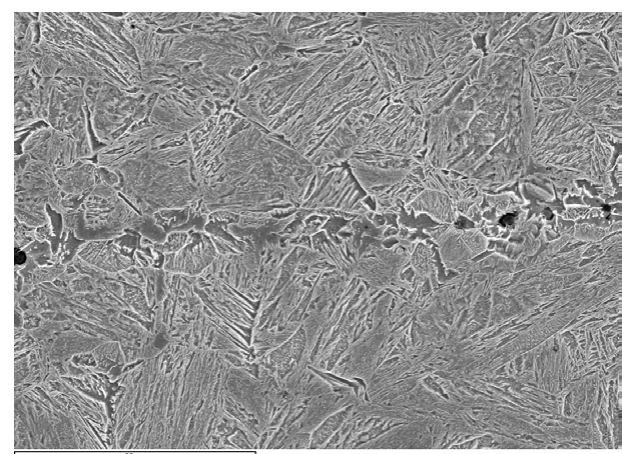

Figure 22: Welded assembly by forge subjected to heat treatment of hardening and tempering. The ferrite band of the interface is observed. 
type of hardening only applied to the blade, the rest of the weapon remains practically untempered (Figure 24).

The Spanish steel must go through a tempering stage to eliminate tension and bitterness. This tempering was carried out at $400^{\circ} \mathrm{C}$ for 15 minutes, obtaining excellent hardness data (Figure 25).

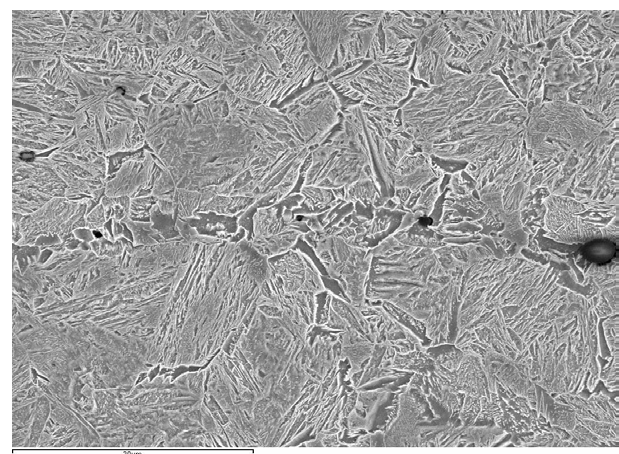

Figure 23: Detail of the previous figure.

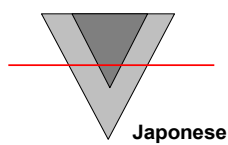

Hardness profile

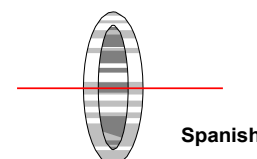

\begin{tabular}{|c|c|c|c|}
\hline MEASURES & $\begin{array}{c}\text { SPECIMEN } \\
\text { AREA }\end{array}$ & $\begin{array}{c}\text { HARDNESS VICKERS } \\
\text { (HV30) }\end{array}$ & $\begin{array}{c}\text { HARDNESS ROCKWELL C } \\
\text { (HRc) }\end{array}$ \\
\hline 1 & Steel & 862 & 65 \\
\hline 2 & Steel & 823 & 64 \\
\hline 3 & Steel & 836 & 65 \\
\hline 4 & Interface & 312 & 31 \\
\hline 5 & Iron & 205 & 14 \\
\hline 6 & Iron & 196 & 13 \\
\hline 7 & Iron & 199 & 14 \\
\hline 8 & Interface & 320 & 33 \\
\hline 9 & Steel & 827 & 64 \\
\hline 10 & Steel & 856 & 65 \\
\hline 11 & Steel & 860 & 65 \\
\hline
\end{tabular}

Figure 24: Vickers hardness profile of the cross-sectional section of Spanish and Japanese tempered steel sheets.

\begin{tabular}{|c|c|c|c|}
\hline MEASURE & SPECIMEN AREA & HARDNESS VICKERS (HV30) & HARDNESS ROCKWELL C (HRC) \\
\hline 1 & Hard steel & 561 & 52 \\
\hline 2 & Hard steel & 561 & 52 \\
\hline 3 & Hard steel & 561 & 52 \\
\hline 4 & Hard steel & 561 & 52 \\
\hline 5 & Interface & 390 & 39 \\
\hline 6 & Interface & 220 & 18 \\
\hline 7 & Soft steel & 190 & 12 \\
\hline 8 & Soft steel & 190 & 12 \\
\hline 9 & Soft steel & 200 & 14 \\
\hline 10 & Soft steel & 203 & 14 \\
\hline 11 & Soft steel & 214 & 16 \\
\hline 12 & Interface & 329 & 33 \\
\hline 13 & Interface & 377 & 37 \\
\hline 14 & Hard steel & 561 & 52 \\
\hline 15 & Hard steel & 561 & 52 \\
\hline 16 & Hard steel & 561 & 52 \\
\hline
\end{tabular}

Spanish Steel

Hardness profile

Figure 25: Vickers hardness profile of the cross section of the Spanish sheet steel tempered in water and tempered at $400^{\circ} \mathrm{C}$ for 15 minutes.
In this way they combine in a remarkable tenacity in the core of the weapon and hardness on the surface, for the case of Spanish steel and, extremely hard the edge of the weapon and, the rest of the blade, tenacious.

\section{Conclusions}

The manufacture of Spanish and Japanese knives is based on the same technological principle. The use of a set of two steels of different composition in carbon joined by forging welding, which compensates the negative mechanical properties with the positive ones that both have. Thus, if individually, the soft steel is not resistant (soft) and, the hard steel, can be fragile; associating the two in a set, this one presents an excellent combination of characteristics of a remarkable cutting edge and excellent tenacity.

The differences appear when the two steels together are associated in somewhat different geometries, depending on the objectives of the type of combat: in Spanish steel, with fencing taking precedence and, in Japanese, mainly cutting.

The forging welding of both high and low carbon steels creates a band of ferrite crystals in the joining zone, which translates into excellent tenacity. The hardening of the set respects this joining zone, allowing an excellent continuity between hard and soft steel, despite the possible diffusion layers that could have been created during forging. The ferrite band always marks the joining zone, visible in many cases, as it contains slag and oxides from the interfaces of welded steel.

\section{References}

1. Del Fraxvo C, De Bouligny J (1850) Memoria sobre la teoría y fabricación del acero en general y de su aplicación a las armas blancas. Imprenta de D. Eduardo Baeza, Segovia.

2. MORLA TD (1784) Tratado de Artillería para el uso de la Academia de Caballeros Cadetes del Real Cuerpo de Artillería, Dividido en Quatro Tomos, que tratan de las principales funciones de los Oficiales de este Cuerpo en Paz y en Guerra.

3. de Paula Mellado F, Bailly-Baillière C (Eds.) (1857) Diccionario de artes y manufacturas, de agricultura, de minas, etc: BE (Vol. 2). en la Librería Española.

4. González H (1989) Fábrica de armas blancas de Toledo: resumen histórico. Imprenta de Menor Hermanos, Toledo.

5. Mas y Zaldúa $L$ (2013) Lecciones de química e industria militar explicadas en la Escuela Superior de Guerra [Texto impreso].

6. Shen-zhang $H$ (1997) Technological study of the roll-forging forming of swords. Journal of materials processing technology 63: 265-268.

7. Notis MR (2000) The history of the metallographic study of the Japanese sword. Materials characterization 45: 253-258.

8. Taleff EM, Bramfitt BL, Syn CK, Lesuer DR, Wadsworth J, et al. (2001) Processing, structure, and properties of a rolled, ultrahigh-carbon steel plate exhibiting a damask pattern. Materials Characterization 46: 11-18.

9. Dueñas Beraiz G (2003) Francisco de Santiago y Palomares y los espaderos toledanos. Gladius 23: 269-305.

10. Park JS (2004) Traditional Japanese sword making from a Tatara ingot as estimated from microstructural examination. ISIJ international 44: 1040-1048.

11. Criado AJ Portal (2007) A metallographic examination of a Toledo steel sword Praktische Metallographie 44: 172-181.

12. Das AK, Ohba T, Morito S, Takami G, Fujikawa T, et al. (2009) Characteristic feature found in typical TATARA product, japanese sword. In European Symposium on Martensitic Transformations (p. 02024). EDP Sciences.

13. Okayasu M (2015) Mechanical Properties of Samurai Swords (Carbon Steel) Made Using a Traditional Steelmaking Technology (tatara). Journal of Materia Sciences \& Engineering 4: 1-6. 
Citation: Duarte A, Queirós GW, Sanchez LG, de Salazar JMG, Portal AJC (2018) Welding by Hot Forging of Two Carbon Steels for the Manufacture of Spanish and Japanese Weapons. J Material Sci Eng 7: 446. doi: 10.4172/2169-0022.1000446

14. Yaso M, Takaiwa T, Minagi Y, Kubota K, Morito S, et al. (2009) Study of Microstructures on Cross Section of JAPANESE SWORD. In European Symposium on Martensitic Transformations (p. 07018). EDP Sciences.

15. Juleff G (2009) Technology and evolution: a root and branch view of Asian iron from first-millennium BC Sri Lanka to Japanese steel. World Archaeology 41: 557-577

16. Inoue T (2010) Tatara and the Japanese sword: the science and technology. Acta Mechanica 214: 17-30.
17. Das AK, Takami G, Takuya OHBA, Morito S, Yaso M (2010) Traditional Process Produces Lath Martensite Effectively. Materials Australia 43(3).

18. Matsumoto C, Das AK, Ohba T, Morito S, Hayashi T, et al. (2013) Characteristics of Japanese sword produced from tatara steel. Journal of Alloys and Compounds 577: S673-S677.

19. Yaso M, Takaiwa T, Minagi Y, Kanaizumi T, Kubota K, et al. (2013) Study of Japanese sword from a viewpoint of steel strength. Journal of Alloys and Compounds 577: S690-S694. 